\title{
DEMOKRASI BARAT: PROBLEM DAN IMPLEMENTASI DI DUNIA
}

\author{
Oleh: \\ Shofwan Rozi dan Heriwanto, \\ Dosen Institut Agama Islam Negeri (IAIN) Bukittinggi \\ Dosen Sekolah Tinggi Agama Islam Mulia Asturi ( STAIMAS) Wonogiri \\ rinawatiyoungentrepreneurship@gmail.com
}

\begin{abstract}
Tampaknya terjadi kecenderungan global di mana demokrasi tidak lagi sekedar menjadi wacana intelektual (intellectual discourse), melainkan obsesi politik berbagai negara, khususnya negara -negara berkembang. Indonesia adalah salah satu negara yang berpenduduk Muslim terbesar di dunia dan salah satu negara yang menganut sistem demokrasi terbesar ketiga di dunia setelah negara India dan Amerika Serikat. Dari berbagai pengalaman pemilihan umum dan penerapan demokrasi di negeri-negeri Islam atau di Barat sendiri, tampak jelas bahwa pemilu adalah alat penjajahan untuk kepentingan Barat. Dari berbagai pengalaman demokrasi negeri-negeri Islam tersebut kita juga bisa mengambil pelajaran bahwa demokrasi hanya menghantarkan perubahan rezim, bukan perubahan pada sistem. Jalan demokrasi ini demikian masif ditawarkan dan dipaksakan Barat di negeri-negeri Islam sebagai sebuah solusi atas berbagai krisis yang melanda. Demokrasi memuluskan liberalisasi ekonomi sebagai alat penjajahan Barat untuk merampok kekayaan alam negeri Islam. Demokrasi juga sebagai alat untuk mengokohkan boneka Barat dan melegitimasi penjajahan mereka atas dunia Islam.
\end{abstract}

Kata Kunci: Demokrasi, Barat, Muslim, dan Problem

\section{A. Pendahuluan}

Teori klasik tampaknya menjelaskan bahwa demokrasi adalah pemerintahan rakyat. Rakyat memiliki hak untuk memerintah. Istilah demokrasi berasal dari bahasa Yunani, yaitu demos adalah rakyat, kratos atau kretein adalah kekuasaan atau berkuasa. ${ }^{1} \quad$ Menurut asal kata berarti rakyat berkuasa atau goverment by the people. Kata "rakyat" yang dipahami di zaman Yunani kuno (Athena), berbeda sekali dengan apa yang kita pahami

${ }^{1}$ I Dewa Gede Atmaja, Konsepsi Demokrasi dalam Bingkai Konstitusi, (Malang: Setara Press, 2011), hlm.5. 
saat ini. Bagi Yunani kuno istilah "rakyat" tidak lebih dari sekumpulan manusia dari sebuah polis atau kota kecil. $^{2}$ Demokrasi adalah bentuk atau sistem pemerintahan yang segenap rakyatnya turut serta memerintah melalui perantara wakilnya (pemerintahan rakyat). ${ }^{3}$

Demokrasi adalah bagian khazanah dalam membuat keputusan secara kolektif. Sistem demokrasi berusaha mewujudkan keinginan bahwa keputusan yang mempengarui perkumpulan secara keseluruhan harus diambil oleh semua anggota dan masing-masing anggota mempunyai hak yang sama dalam proses pengambilan atau pembuatan keputusan. Dengan kata lain, demokrasi memiliki prinsip kembar sebagai kontrol rakyat atas proses pembuatan keputusan secara kolektif dan memiliki kesamaan hak dalam mengendalikan hal itu. ${ }^{4}$

Demokrasi menyangkut aturan manusia, aturan majelis, aturan partai, aturan umum, kediktatoran kaum ploretar, partisipasi politik, kompetisi para elite dalam meraih suara, multipartai, pluralisme sosial dan politik, persamaan hak, kebebasan berpolitik dan sipil, sebuah masyarakat yang bebas, ekonomi pasar bebas, dan lain-lain. Demokrasi adalah suatu

${ }^{2}$ Muhammad Rizza Sihbudi, "Islam, Radikalisme dan Demokrasi" (Jakarta: Lembaga Ilmu Pengetahuan Indonesia, 2004), hlm.5.

3 Badan Pengembangan dan

Pembinaan Bahasa, Kamus Bahasa Indonesia untuk Pelajar, (Jakarta: Kementrian Pendidikan dan Kebudayaan, 2011), hlm.91.

4 David Beetham dan Kevin Boyle, Demokrasi: 80 Tanya Jawab, (Yogyakarta: Kanisius, 2000), hlm.19-20. bentuk pemerintahan dimana kekuasaan tertinggi berada ditangan rakyat, dilaksanakan langsung oleh mereka atau oleh wakil terpilih dalam sistem pemilu yang bebas. Definisi lain demokrasi adalah partisipasi rakyat. ${ }^{5}$ Demokrasi bertalian dengan hubungan antara penguasa dan rakyat, dalam pengertian sejauh mana peran serta rakyat dalam menetapkan kekuasaan pemerintah di dalam suatu Negara disatu sisi berhadapan dengan hak-hak dan kekuasaan pemerintah terhadap rakyat pada sisi lain. Artinya hubungan antara yang memerintah dan yang diperintah. $^{6}$

Demokrasi juga diasosiasikan suatu bentuk pemerintahan dimana keputusan-keputusan penting pemerintahan atau garis kebijakan di belakang keputusan-keputusan tersebut secara langsung atau tidak langsung hanya dapat berlangsung jika disetujui secara bebas oleh mayoritas masyarakat dewasa yang berada dalam posisi diperintah. ${ }^{7}$ Sistem politik yang demokratis adalah dimana kebijakan umum ditentukan atas dasar mayoritas oleh wakil-wakil yang diawasi secara efektif oleh rakyat dalam pemilihanpemilihan berkala yang didasarkan atas prinsip kesamaan politik dan

${ }^{5}$ Bernard Lewis, Islam Liberalisme Demokrasi: Membangun sinergi warisan Sejarah, Doktrin, dan Konteks Global, (Jakarta: Paramadina, 2002), hlm.3.

${ }^{6}$ Muhammad Alim, Demokrasi dan Hak Asasi Manusia dalam Konstitusi Madinah dan UUD 1945, (Yogyakarta: UUI Press, 2001), hlm.1.

${ }^{7}$ Mujar Ibnu Syarif dan Khamami Zada, Fiqh Siyasah: Doktrin dan Pemikiran Politik Islam (Jakarta: Erlangga, 2007), hlm. 216. 
diselenggarakan dalam suasana terjaminya kebebasan politik. ${ }^{8}$

Demokrasi bermakna variatif dan bersifat interpretatif. Kita mengenal berbagai tipologi demokrasi. Setiap negara berhak mengklaim sebagai negara yang demokratis, meskipun nilai dan praktik politik kekuasaanya jauh dengan prinsipprinsip demokrasi. Demokrasi juga bersifat evolutif dan dinamis, demokrasi bukan konsep yang statis. Demokrasi selalu mengalami perubahan, baik bentuk formalnya maupun substansinya sesuai dengan konteks dan dinamika sosio-historis dimana konsep demokrasi lahir dan berkembang. Demokrasi juga berkembang secara evolutif, secara perlahan tapi pasti. Konsep dan implementasi tidak harus sesuai dengan demokrasi pada zaman Yunani kuno.

Demokrasi semakin berkembang di Barat seiring lahirnya gerakan renaisans pada abad XIV dan gerakan reformasi pada abad ke XVI-XVII. Gerakan Renaisans melahirkan gagasan-gagasan demokrasi dengan perjuanganya menentang kekuasaan gereja yang absolut yang mengatasnamakan agama, desakralisasi gereja, memperjuangkan kebebasan beragama, kebebasan berfikir dan mengemukakan pendapat dan mempelopori terbentuknya negara bangsa. Gerakan reformasi melahirkan penemuan baru tentang teknologi yang sangat bermanfaat bagi kaum intelektual untuk menyebarkan gagasan intelektualnya dan konsep demokrasi. Pada masa inilah gagasan-gagasan demokrasi menjadi perhatian dan

${ }^{8}$ Ni'matul Huda, Negara Hukum, Demokrasi dan Judicial Review, (Yogyakarta: UII Press, 2005), hlm.13. kajian para pemikir Barat seperti Jean Bodin, Thomas Hobbes, Rousseau, Locke, Voltaire, Montesquieu, dan pemikir Barat lainya. ${ }^{9}$

$$
\text { Jean Bodin sangat terkenal }
$$
dengan filsafatnya tentang masalah kemasyarakatan dan kenegaraan. Hegemoni kaum gereja di Prancis begitu besar dan peperangan antara kaum Huguenot berlarut-larut yang menimbulkan banyak korban. Jean Bodin mengusulkan agar diciptakan suasana toleransi beragama dan memberikan keleluasaan pada golongan protestan untuk menjalankan ajaran agamanya sesuai dengan keyakinan yang dianut. Kekuasaan dan kedaulatan negara dipercayakan pada Raja. ${ }^{10}$ Konsep tersebut malahirkan kosep teori kedaulatan. Gagasan teori kedaulatan ini membawa implikasi pada terbentunya sentralisasi administrasi dan batasan teretorial negara relatif jelas. Komunitas politik dipandang lebih otonomi, tidak lagi tunduk dibawah otoritas kaum gereja. Teori kedaulatan Jean Bodin telah menjadi pijakan bagi pembentukan gagasan demokrasi modern. ${ }^{11}$ Jean Bodin ini berhasil menyelamatkan Prancis dari kekacauan akibat sengketa antar agama yang berlarut-larut dan dianggap sebagai cikal bakal terbentuknya konsep negarakebangsaan (nation-state) dengan kekuasaan dan kedaulatan terpusat pada Raja. Pada akhir abad ke 19 gagasan mengenai demokrasi mendapat

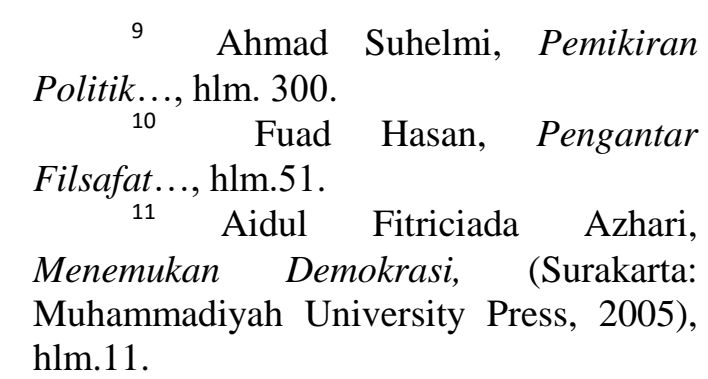


wujud yang kongkret sebagai program dan sistem politik. Demokrasi pada tahap ini semata-mata bersifat politis dan mendasarkan dirinya atas asas-asas kemerdekaan individu, kesamaan hak (equal right), serta hak pilih untuk semua warga negara (universal suffrage). ${ }^{12}$

Perkembangan demokrasi di Indonesia telah mengalami pasang surut. Masalah pokok yang dihadapi ialah bagaimana dalam masyarakat yang beraneka ragam pola budayanya, mempertinggi tingkat kehidupan ekonomi disamping membina suatu kehidupan sosial politik yang demokratis. Masalah ini berkisar pada penyusunan suatu sistem politik, dimana kepemimpinan cukup kuat untuk melaksanakan pembangunan ekonomi serta nation building, dengan partisipasi rakyat seraya menghindarkan kediktatoran. Perkembangan sejarah demokrasi Indonesia Prof. Miriam Budiardjo membagi menjadi empat masa, ${ }^{13}$ yaitu:

a).Masa Republik Indonesia I (1945-1959), yaitu masa demokrasi (konstitusional) yang menonjolkan peranan parlemen serta partai-partai dan karena itu dapat dinamakan demokrasi parlementer. 2). Masa Republik Indonesia II (1959-1965), yaitu demokrasi terpimpin yang dalam banyak aspek telah menyimpang dan demokrasi konstitusional yang secara formal merupakan landasannya, dan menunjukan beberapa aspek demokrasi rakyat.

3).Masa Republik Indonesia III (1965-1998), yaitu masa

12 Miriam Budiardjo, Dasardasar..., hlm.111-112.

${ }^{13}$ Ibid, hlm.127-128. demokrasi pancasila yang merupakan demokrasi konstitusional yang menonjolkan sistem presidensial. 4).Masa Republik Indonesia IV (1998sekarang), yaitu masa reformasi yang menginginkan tegaknya demokrasidi Indonesia sebagai koreksi terhadap praktek-praktek politik yang terjadi pada masa Republik Indonesia III.

Tampaknya terjadi kecenderungan global di mana demokrasi tidak lagi sekedar menjadi wacana intelektual (intellectual discourse), melainkan obsesi politik berbagai negara, khususnya negaranegara berkembang. Indonesia adalah salah satu negara yang berpenduduk Muslim terbesar di dunia dan salah satu negara yang menganut sistem demokrasi terbesar ketiga di dunia setelah negara India dan Amerika Serikat.

\section{B. Demokrasi dan Problem Implementasi di Negara Muslim}

Penelitian yang dilakukan UNESCO pada tahun 1949, menarik kesimpulan bahwa ide demokrasi dianggap ambiguous atau mempunyai berbagai pengertian, sekurangkurangnya ada ambiguity mengenai lembaga-lembaga atau cara-cara yang dipakai untuk melaksanakan ide atau mengenai keadaan kultural secara historis yang mempengarui istilah, ide, dan praktek demokrasi. ${ }^{14}$

Demokrasi bukanlah bentuk pemerintahan yang ideal, mereka menilai demokrasi sebagai

\footnotetext{
${ }^{14}$ Ibid, hlm.105.
} 
pemerintahan oleh rakyat miskin. ${ }^{15}$ Walaupun demokrasi berasal dari Yunani kono, tetapi di mata para pemikir sendiri seperti Plato dan Aristoteles demokrasi bukanlah bentuk pemerintahan yang ideal. Demokrasi pada zaman Yunani hanya memberikan hak berpartisipasi politik pada minoritas kecil kaum laki-laki yang telah dewasa. Beda dengan demokrasi Modern yang syarat dengan gagasan mengenai hak dan kebebasan individu. Di Barat pandangan yang negatif atas demokrasi ini bertahan selama lebih dari dua ribu tahun hingga abad ke $17 .^{16}$

Sebelum abad ke-18, demokrasi bukanlah sistem yang dipilih umat manusia. Sistem ini ditolak di era Yunani dan Romawi dan hampir semua filosof politik menolaknya. Sejak abad ke-18, beberapa aspek dari demokrasi politik mulai diterapkan di Barat. Akan tetapi masih juga mendapat kritik yang keras. Leislie Lipson melihat tiga keberatan dalam sistem demokrasi:

Pertama, Potensi tirani mayoritas terhadap kelompok minoritas. Kedua, kenyataan bahwa demokrasi cenderung menempatkan orang-orang bodoh dalam tupuk kekuasaan. Ketiga, demokrasi hanya berupa ilusi, jika bukan kebohongan. Utopi belaka, bahkan lebih buruk adalah kepalsual demokrasi, yang menurut argumentasi ini adalah sesuatu yang berpura-pura

15 Aidul Fitricida Azhari, Tafsir Konstitusi: Pergulatan Mewujudkan Demokrasi di Indonesia (Solo: Jagad Abjad, 2010). hlm.80.

${ }^{16}$ Aidul Fitricida Azhari, Menemukan..., hlm.1. membantu dan melindungi minoritas. 17

Plato (429-347 SM) pernah mengingatkan kelemahan dan bahaya internal demokrasi. Pemimpin biasanya dipilih dan diikuti karena faktor-faktor non-esensial, seperti kepintaran pidato, kekayaan, dan latar belakang keluarga. Demokrasi sebagai tatanan yang menjamin terbukanya peluang bagi setiap warga negara untuk berperan dalam tugas kemasyarakatan dan kenegaraan, dengan catatan bahwa tugas tersebut diandalkan pada kemampuan seorang. Plato memimpikan munculnya "The wisest people" sebagai pemimpin ideal di suatu Negara. "The wisest people is the best people in the state, who would approach human problems with reason and wisdom derived from knowledge of the world of unchanging and perfect ideas." 18

Plato menyatakan bahwa dalam demokrasi persatuan tidak dapat diraih, karena adanya prinsip-prinsip yang mendasari sistem. Prinsip demokrasi adalah kebebasan (liberty), karena semua itu adalah kebebasan setiap pola personifikasi berkembang. Keberagaman atau variasi menjadi bukti bahwa persatuan tidak akan pernah tercapai. Plato menambahkan demokrasi dipengarui oleh penyakit persamaan (disease of equality) dan dipengarui juga oleh gejala equality. Prinsip equality adalah semua orang memiliki hak yang sama dalam hlm.114.

17 Muslim Mufti, Teori-teori..., 18 Adian Husaini, Menimbang Kembali..., hlm.15. 
demokrasi, baik orang kaya maupun orang miskin. ${ }^{19}$

Aristoteles mengingatkan bahwa, rakyat adalah sebagai katagori warga negara (citizen). Mereka adalah kelompok sosial minoritas dalam negara kota (polis atau city state) yang memiliki hak-hak istimewa dalam kehidupan politik kota. Tatanan bernegara tidak mungkin dijamin stabil apabila nasibnya ditentukan oleh suara orang banyak dan harus setiap waktu diubah untuk memenui selera mereka. Tata negara harus dipercayakan pada mereka yang sesungguhnya mampu mengelolanya. ${ }^{20}$

Ditangan Rakyatlah nasib negara kota ditentukan. Mayoritas penduduk negara Yunani saat itu adalah budak belian dan pedagangpedagang Asing yang berasal dari kawasan luar dan mereka ini tidak memiliki hak-hak istimewa seperti kaum warga negara. Mereka adalah kelompok sosial kelas dua dalam struktur negara demokratis dimasa Yunani kuno. Atas anggapan ini tampak bahwa demokrasi sejak lahir dimasa Yunani kuno sudah cacat. ${ }^{21}$

Aristoteles (384-322 SM) juga menyebut demokrasi sebagai bentuk pemerintahan buruk, seperti tirani dan oligarki. ${ }^{22}$ Aristoteles berpendapat;

19 Muslim Mufti, Teori-Teori Politik, (Bandung: Pustaka Setia, 2012), hlm 108. hlm.51.

${ }^{20}$ Fuad Hasan, Pengantar Filsafat...,

1 Ahmad Suhelmi, Pemikir Politik..., hlm.298.

22 Adian Husaini, Demokrasi: Sejarah, Makna dan Respon Muslim, makalah dalam Seminar Nasional tentang Islam dan demokrasi di Universitas Muhammadiyah Surakarta, 28 Februari 2009. hlm.8.
"Demokrasi memunculkan kekuasaan berdasarkan hasil suara terbanyak sama timpangnya dengan aristokrasi yang mempertahankan kekuasaan berdasarkan keturunan belaka. Aristoteles menyebut demokrasi sebagai bentuk pemerintahan atau negara yang buruk (bad state) bukan negara yang baik (good state)". 23

Demokrasi kurang baik karena merupakan pemerintahan orang banyak, dimana satu sama lain memiliki perbedaan atau pertentangan kepentingan, latar belakang sosial ekonomi dan perbedaan tingkat pendidikan yang mencolok. Pemerintahan yang dilakukan oleh mayoritas penduduk itu akan mudah berubah menjadi pemerintahan yang anarkis, menjadi ajang pertempuran konflik kepentingan berbagai berbagai kelompok sosial dan pertarungan elite kekuasaan. Seperti itulah yang menjadi kendala bagi terwujudnya pemerintahan yang baik. Konsensus sulit dicapai dan konflik mudah terjadi karena perbedaan-perbedaan itu.

Dalam pandangan Leislie Lipson terdapat tiga paradoks dalam sistem demokrasi Barat, yaitu:

Pertama, potensi tirani mayoritas terhadap kelompok minoritas. Tirani berkaitan dengan tidakan yang sewenang-wenang dari kelompok kecil masyarakat kepada kelompok mayoritas dan penyangkalan terhadap hak-hak kaum minoritas. Kedua, kenyataan bahwa demokrasi cenderung menempatkan orang-orang bodoh dalam tampuk kekuasaan. Seni

${ }^{23}$ Ibid, hlm.54. 
pemerintahan

memerlukan

seseorang yang ahli dan mengerti secara teknis mengenai pemerintahan. Ketiga, demokrasi berupa Ilusi, jika bukan kebohongan. Yaitu sesuatu yang berpura-pura membantu dan melindungi mayoritas. ${ }^{24}$

Muhammad Iqbal juga memberikan kritik terhadap konsep Demokrasi yang menyerahkan keputusannya kepada massa yang berpikiran rendah. Menurut Muhammad Iqbal bagaimanapun para semut tidak akan mampu melampui kepintaran seorang Sulaiman. ${ }^{25}$ Muhammad Iqbal mengajak meninggalkan konsep demokrasi.

Do you seek the wealth of meaning from low natured men? From ants cannot proceed the brilliance of a Solomon. Flee from the methods of democracy because human thinking can not issue out of the brains of two hundred asses. ${ }^{26}$

Kemunafikan Barat soal demokrasi, juga terlihat bagaimana Barat memperlakukan negaranegara Muslim sesuai keuntunganya sendiri. Sistem demokrasi dapat ditoleransi jika yang berkuasa atau yang menang adalah kelompok sekuler atau liberal. Jika yang menang adalah kelompok yang anti Barat, tidak segan-segan Barat akan hlm. 114

24 Muslim Mufti, Teori-teori...,

25 Adian Husaini, Menimbang Kembali..., hlm.15.

26 Marvin Perry, Western Civilization: A Brief History, (Boston: Houghton Mifflin Company, 1997), hlm. 63. menggulingkan kekuasaan tersebut. Berbagai intervensi dan tekanan dilakukan agar pemenang pemilu yang tidak pro dengan Barat tersebut segera tubang.

Amerika Serikat sebagai simbol demokrasi dunia telah mengingkari prinsip demokrasi itu sendiri. Jika gabungan kata demos dan krotos diartikan sebagai pemerintahan oleh rakyat (government by the people), maka pemerintahan yang demokratis diindikasikan dengan dukungan mayoritas rakyat terhadap pemerintahan terpilih. Amerika Serikat bukan negara yang demokratis, walaupun mereka menggambarkan dirinya sebagai demokratis. Sistem pemerintahan yang terjadi adalah totaliter dan sama sekali tidak mengahargai undang-undang dasarnya. ${ }^{27}$

Pemilian Presiden pada tahun 2000 di Amerika Serikat sebagai contoh buruknya implementasi demokrasi. Mahkamah Agung (US Supreme Court), memenangkan George W. Bush atas Al-Gore. Hal ini memunculkan problem sangat serius dikalangan tokoh-tokoh Amerika Serikat. Negara adidaya sebagai simbol demokrasi dunia justru pemilihan kepala negara, akhirnya diserahkan keputusanya kepada lima orang hakim di Mahkamah Agung (US Supreme Court). Padahal yang terjadi suara rakyat (popular vote) lebih banyak berpihak kepada al-Gore dengan jumlah pemilih mencapai 60 $\%$ dari rakyat Amerika Serikat, tapi

${ }^{27}$ Jerry D. Gray, Demokrasi Barbar Ala Amerika, (Jakarta: Sinergi Publishing, 2007), hlm.192 
faktanya presiden Amerika Serikat didukung oleh minoritas rakyatnya. 28

Bukti kemunafikan demokrasi Barat juga dirasakan dinegaranegara muslim. Khasus FIS di negara Aljazair menjadi bukti yang sangat fatal. Meskipun yang menang pemilu secara demokrastis adalah FIS, namun akhirnya pada awal Januari 1992 militer garis keras di Aljazair dengan dukungan penuh Prancis dan Amerika Serikat membatalkan pemilu dengan sepihak. Barat telah memainkan peran yang inkonsisten dan munafik, ini nampak jelas bahwa kudeta yang dilakukan oleh militer Aljazair justru mendapat apresiasi oleh pemerintahan Amerika Serikat. 29

Di negara Turki, Partai Raffah muncul sebagai pemenang dalam pemilu yang demokratis. Kemenangan patai Rafah juga mengindikasi kemenangan awal Islam dalam pertarungan selama 72 tahun terakhir melawan sekulerisme. Erbakan meskipun telah berhasil memenangkan pemilu secara demokratis pada tahun 1997 tetap saja tidak disukai Barat dan mendapat tekanan yang begitu kuat dari militer. Sudah menjadi watak Barat bahwa dukungan-dukungan politik lebih pada rezim-rezim otoriter dan fasis di dunia, tetapi masih saja terus menerus

${ }^{28}$ Adian Husaini, Wajah Peradaban Barat: dari Hegemoni Kristen ke dominasi sekular liberal, (Jakarta:Gema Insani,2005), hlm.88

${ }^{29}$ Adian Husaini, Islam Liberal: Sejarah, Konsepsi, Penyimpangan dan Jawaban, (Jakarta:Gema Insani,2002), hlm.203 mengkampanyekan pengembangan demokrasi. Setelah hampir 20 bulan memerintah Erbakan terguling pada Juni 1997. Lebih tragis lagi partai Rafah dibubarkan oleh pihak militer. ${ }^{30}$

Di negara Palestina, demokrasi mampu mengadu-domba rakyat Palestina. Hamas mendapat simpati dari dunia Islam dan rakyat Palestina dengan Intifadhanya. Faksi Fatah dibawah kendali Barat tidak ingin kehilangan pengaruh. Pemilu kemudian ditawarkan oleh Barat sebagai solusi krisis Palestina pada tahun 2006-2007. Hamas menang dalam pemilu tersebut, Barat mulai kawatir karena Hamas tetap tidak akan berdamai dengan negara Zionis Yahudi. Berbagai tekanan akhirnya dilakukan terhadap Hamas walaupun dalam pemilian umum Hamas menang secara demokrasi. Palestina akhirnya pecah, Hamas berkuasa di Jalur Gaza dan Fatah di Tepi Barat.

Di negara Mesir, Mursi sebagai presiden terpilih dan menang secara demokrasi juga tumbang oleh kudeta militer yang didukung oleh Barat. Militer dibawah Jendral as-Sisi melakukan berbagai provokasi untuk menghancurkan Mursi dan pengikutnya. Meskipun Mursi tampil secara moderat, Amerika Serikat tetap saja merasa kawatir, karena beranggapan Mursi mengarah ke sistem Islam. Barat mendukung penuh kudeta yang dilakukan as-Sisi dan berpura-pura mengecam kodeta tesebut sebagai pelanggaran Hak Asasi Manusia.

30 Asep Syamsul M. Romli, Demonologi Islam: Upaya Barat Membasmi Kekuatan Islam, (Jakarta: Gema Insani, 2000), hlm.84-85 
Amerika Serikat lebih merasa aman jika mesir di bawah kendali militer, yang oleh Amerika Serikat dikontrol penuh dengan bantuan dana yang sangat besar setiap tahun nya.

Demokrasi dibeberapa wilayah Islam, digunakan untuk mengokohkan penguasa boneka Barat. Di Yaman, pemilu demokratis dugunakan untuk memuluskan pergantian rezim baru pengganti Abdullah Saleh. Dalam pemilu 2012 terpilih Masour Hadi yang sebelumnya menjabat sebagai wakil presiden Yaman. Di Irak, lewat pemilu demokratis tahun 2013 koalisi Maliki menang dengan dukungan penuh Amerika Serikat. Begitu juga di negara Afganistan, pemilu diselenggarakan untuk mengokohkan rezim boneka Amerika Serikat. Pemilu pada tahun 2014 mantan menteri luar negeri Abdullah menduduki urutan pertama dalam perhitungan suara awal. Partisipasi rakyat dalam pemilian umum sangat rendah, sehingga legitimasi pemilu tersebut diragukan. Hasil perhitungan suara adalah banyak yang direkayasa. $\quad \mathrm{Di}$ negara Prancis sebagai negara yang menganut demokrasi juga justru tidak relevan dengan prinsip-prinsip fundamental dalam demokrasi sendiri. Pada kenyataanya dinegara tersebut warganegara Muslim justru dilarang untuk berjilbab. Padahal jilbab untuk melindungi warganegara Muslim agar aman dan terhidar dari fitnah. Justru di Prancis tindak asusila seperti kawin sejenis (homosexual/ lesbian) justru tidak dilarang dan bahkan mendapat perlindungan dari pemerintah. Perbuatan tersebut sangat jelas merusak moral dan martabat manusia. Hal ini sangat paradoks dan tidak sesuai dengan prinsip demokrasi. ${ }^{31}$

Dari berbagai pengalaman pemilihan umum dan penerapan demokrasi di negeri-negeri Islam atau di Barat sendiri, tampak jelas bahwa pemilu adalah alat penjajahan untuk kepentingan Barat. Dari berbagai pengalaman demokrasi negeri-negeri Islam tersebut kita juga bisa mengambil pelajaran bahwa demokrasi hanya menghantarkan perubahan rezim, bukan perubahan pada sistem. Jalan demokrasi ini demikian masif ditawarkan dan dipaksakan Barat di negeri-negeri Islam sebagai sebuah solusi atas berbagai krisis yang melanda. Demokrasi memuluskan liberalisasi ekonomi sebagai alat penjajahan Barat untuk merampok kekayaan alam negeri Islam. Demokrasi juga sebagai alat untuk mengokohkan boneka Barat dan melegitimasi penjajahan mereka atas dunia Islam.

\section{Dilema Demokrasi di Indonesia}

Sebuah negara demokrasi, kekuasaan tertinggi berada ditangan rakyat, bukan penguasa. ${ }^{32}$ Azyumardi Azra dalam acara hari demokrasi internasional di New York pada 12 September 2008 nampaknya tetap

31 Yusuf Al-Qaradhawi, Larangan Berjilbab (Studi Khasus di Prancis), (Jakarta:Gema Insani, 2004), hlm.63

32 Masyur Semma, Negara dan Korupsi: Pemikiran Mochtar Lubis Atas Negara, Manusia Indonesia dan Perilaku Politik, (Jakarta:Yayasan Obor Indonesia,2008), hlm.175. 
mengagungkan demokrasi. Kegiatan ini bertitik tolak dari kepedulian tentang kaitan antara demokrasi dan pembangunan, sebaliknya antara pembangunan dan demokrasi. Memang dalam beberapa kasus pertumbuhan demokrasi tidak selalu berjalan beriringan dengan pembangunan ekonomi dan sosial. Terlihat demokrasi yang memunculkan berbagai konsekuensi yang tidak terduga (unintended conseuences) dan ekses ekses telah menghambat pembangunan. Kasus ini terlihat jelas, misalnya dalam pengalaman Indonesia dimasa sepuluh tahun penerapan demokrasi multipartai yang mengakibatkan terjadinya perlambatan dalam pembangunan ekonomi dan sosial. ${ }^{33}$

Syafii Maarif juga memuji demokrasi secara berlebihan walaupun terdapat beberapa sisi yang dikritik. Menurutnya belum ada satu sistem di dunia di era sekarang ini yang mampu menandingi demokrasi. Kesulitan di era modern adalah kenyataan peradaban umat manusia sampai detik ini belum menemukan sistem yang lebih baik dan lebih unggul dari demokrasi. Selain itu Syafii Maarif juga mengkritik dan menguraikan cacatan demokrasi di Indonesia, perilaku elite politik yang korup, meraup kekayaan negara dan sistem pemilihan langsung yang nilainya mengerikan, yaitu sampai 400 trilyun. Syafii Maarif sepakat demokrasi harus dipertahankan karena menjad pilihan sejak awal, yang harus digugat adalah pelaku demokrasi yang semakin teler, menjadi penikmat demokrasi, sebuah

33 Azyumardi Azra, Artikel Resonansi Republika 25 September 2008, (www. republika. com diakses 31 Oktober 2014). pengkianatan politik di dalam sistem demokrasi. ${ }^{34}$

Demokrasi berarti kedaulatan rakyat, yaitu rakyat yang bebas dan merdeka yang menjadi raja atas dirinya sendiri dan yang dilawankan dengan daulat tuanku. Demokrasi Barat yang diskriminatif bukanlah demokrasi yang sesuai untuk membangun Indonesia merdeka. ${ }^{35}$ Terdapat enam pilar penting dalam demokrasi di Indonesia antara lain partai politik, pemilihan umum, pers, lembaga legislatif, eksekutif, dan yudikatif. ${ }^{36}$ Untuk melaksanakan nilai-nilai demokrasi perlu diselenggarakan beberapa lembaga antara lain Pemerintahan yang bertanggung jawab, Dewan Perwakilan Rakyat, Organisasi Politik, Pers, dan sistem Peradilan. ${ }^{37}$

Partai politik merupakan pilar penting demokrasi di Indonesia. Partai politik adalah institusi politik yang mencari pengaruh dalam suatu negara, dengan tujuan mengisi posisi strategis dalam pemerintahan. Partai politik berusaha mengagregasikan kepentingan masyarakat, sehingga kepentingan masyarakat dapat tersalurkan melalui

${ }^{34}$ Syafii Maarif, Artikel Resonansi Republika 12 Agustus 2008, (www. republika. com diakses 31 Oktober 2014).

35 Zulfikri Sulemen, Demokrasi Untuk Indonesia: Pemikiran Politik Bung Hatta, (Jakarta: Kompas Media Nusantara, 2010), hlm.14.

${ }_{36}$

Syamsuddin Haris,

Demokrasitisasi Partai dan Dilema Sistem

Kepartaian di Indonesia, Jurnal Penelitian Politik, Vol.3, No.1, 2006 (Jakarta: Lembaga Ilmu-Ilmu Pengetahuan Indonesia, 2006) hlm.67.

37 Ni'matul Huda, Negara Hukum, Demokrasi dan Judicial Review, (Yogyakarta: UII Press, 2005), hlm.14. 
partai politik. ${ }^{38}$ Fungsi partai politik di negara demokrasi seperti Indonesia antara lain sebagai sarana komunikasi politik, sebagai sarana sosialisasi politik, sebagai sarana rekrutmen politik, dan sebagai sarana pengatur konflik (conflict management). ${ }^{39}$

Tidak semua partai politik memberikan kontribusi positif terhadap perkembangan demokrasi. Syamsuddin Haris menyatakan:

Terdapat empat kelompok kegagalan parta politik antara lain: pertama kegagalan organisasi atau institusi politik. Kedua, kegagalan kepemimpinan dalam politik. Ketiga, kegagalan idiologi politik. Keempat, kegagalan taktik dan strategi politik. ${ }^{40}$

Gagalnya organisasi politik di Indonesia dialami hampir semua partai politik baik partai nasionalis dan partai Islam. Partai politik tidak memiliki tradisi berorganisasi dengan benar, kolegial, demokratis dan bertanggung jawab. Sebagian besar keputusan politik ditentukan secara sepihak dan oligarki oleh segelintir kelompok atau seorang pemimpin partai. Kegagalan kepemimpinan partai politik karena tidak memiliki orientasi sikap dan tingkah laku, tidak memiliki kematangan etis dan tidak memiliki kualifikasi kemampuan elite partai dalam performance politik mereka. Dalam perspektif ideologi partai, hampir semua politisi cenderung bersifat pragmatis dan tidak konsisten. Kepentingan kelangsungan kekuasaan

38 Muslim Mufti, Teori - Teori..., hlm. 124 .

39 Miriam Budiardjo, Dasar Dasar..., hlm.405-409.

40 Syamsuddin Haris,

Demokrasitisasi Partai dan Dilema..., hlm.67. pribadi dan vasted interest kelompok akhirnya mengalahkan komitmen mereka terhadap ideologi. Dalam konteks taktik dan strategi hampir semua partai terperangkap upaya memperjuangkan jabatan - jabatan publik katimbang perjuangan memenangkan kebijakan publik.

Pengaruh partai politik tengah mengalami penurunan dan kemunduran. Hal itu disebabkan Partai politik dianggap tidak lagi mewakili rakyat banyak. Kehidupan politik modern telah menjadi begitu kompleks dengan bertumbuhnya globalisasi di bidang ekonomi dan bidang-bidang lainya, baik nasional atau internasional. Akibatnya partai politik tidak mampu menyelesaikan beragam masalah. Banyak masalah-masalah baru yang muncul seperti lingkungan dan hak-hak perempuan yang kurang mendapat perhatian. Kritik yang sering dilontarkan adalah bahwa anggotaanggota partai politik yang duduk di parlemen sering melakukan korupsi, cenderung mengutamakan kepentingan pribadi dan golongan daripada kepentingan umum dan cenderung mengejar mengutamakan kedekatan dengan pusat-pusat kekuasaan. ${ }^{41}$

Dikebanyakan negara demokrasi pemilihan umum dianggap lambang, sekaligus tolok ukur dari demokrasi tersebut. Hasil pemilihan umum diselenggarakan dalam suasana keterbukaan dengan kebebasan pendapat dan kebebasan berserikat, dianggap mencerminkan dengan agak akurat partisipasi serta aspirasi masyarakat. sejak kemerdekaan hingga tahun 2014 bangsa Indonesia telah menyenggarakan sebelas kali 41 Miriam Budiardjo, Dasar Dasar..., hlm.420. 
pemilihan umum, yaitu pada tahun 1955, 1971, 1977, 1982, 1987, 1992, 1997, 1999, 2004, 2009, dan 2014 mempunyai kekhususan atau keistimewaan dibanding dengan yang lain.

Pencalonan anggota DPR merupakan salah satu proses dan tahapan penting dalam pemilihan umum (pemilu), termasuk di Indonesia. Melalui proses pencalonan secara teoritis bertemu dengan kepentingakepentingan pragmatis partai - partai politik di satu pihak, dengan aspirasi dan kepentingan rakyat dipihak lain. Oleh karena itu, para calon anggota DPR pada hakekatnya adalah wakil rakyat yang mendapat mandat untuk memperjuangkan kepentingan para pemilihnya di badan-badan legislatif. Namun dalam praktek pemilu di Indonesia, rakyat memilih hanya menjadi subyek dalam proses politik dan pihak yang diwakili oleh partai partai di Dewan Perwakilan Rakyat acapkali tidak merasa terwakili aspirasi dan kepentinganya oleh para anggota parlemen. ${ }^{42}$

Kecenderungan pemilu yang jauh dari etika politik akan membawa dampak negatif. Pertama, rendahnya kualitas keterwakilan para calon dan para wakil rakyat yang duduk dalam lembaga-lembaga legislatif ditingkat nasional dan lokal. Kedua, rendahnya akuntabilitas wakil-wakil terhadap rakyat yang diwakilinya. Ketiga, rendahnya kualitas lembaga-lembaga legislatif itu sendiri sehingga tidak mengherankan jika muncul penilaian

${ }^{42}$ Syamsul Haris, Proses Pencalona Legislatif Lokal: Pola, Kecenderungan DAN Profil Caleg, (Jakarta: Gramedia Pustaka Utama, 2006 ), hlm.1. bahwa DPR tidak lebih sebagai pesuruh partai politik.

Pers dalam konteks demokrasi memili peran yang sangat strategis antara lain, pertama memenuhi hak masyarakat untuk mengetahui. Kedua, menegakan nila-nilai dasar demokrasi, mendorong terwujudnya supremasi hukum dan hak-hak asasi manusia, menghormati kebhinekaan. Ketiga, mengembangkan pendapat umumberdasrkan informasi yang tepat akurat dan benar. Keempat, melakukan pengawasan, kritik, koreksi, dan saran terhadap hal-hal yang berkaitan dengan kepentingan umum. Kelima, memperjuangkan keadilan dan kebenaran. ${ }^{43}$

Kebebasan demokrasi memerlukan kebebasan berekspresi, demokrasi adalah suatu sistem politik yang bersendikan kedaulatan rakyat. Rakyat meilih, dan berpartisipasi, dalam proses politik. Bagi masyarakat pers dan masyarakat luas apa yang menjadi fungsi pers diketahui cukup luas. Yaitu sebagai watch dog, sebagai mata dan telingan, sebagai pemberi isyarat, pemberi tanda - tanda dini, sebagai pembentuk pendapat umum, sebagai pengarah agenda dan lain-lain. Kebebasan pers tidak terlepaskan dari paham kebebasan berfikir, kebebasan berpendapat, kebebasan berbicara. Paham kebebasan pers erat berkaitan dengan sistem politik yang berlaku. Maka pernah dikenal 4 teori kebebasan pers, yaitu: 1). Otoritarian

${ }^{43}$ Agus Sudibyo, Ekonomi Politik Media Penyiaran, (Yogyakarta: LKIS, 2004), hlm.53 
2).Libertarian

3).Marxist-Leninist

\section{4).Tanggung Jawab Sosial. ${ }^{4}$}

Media memiliki kekuasaan untuk membawa pesan politik dan membentuk opini publik. Keefektifan media massa dalam menyampaikan pesan politik telah menjadikanya sebagai ajang baru pertempuran politik. Siapapun yang memiliki akses kepada media massa memiliki kemampuan untuk mengarahkan dan membentuk opini publik sesuai dengan yang diharapkan. Ketika kekuatan politik ingin mendiskreditkan omage politik lawan, yang perlu dilakukan adalah membanjiri informasi di media massa dengan hal-hal buruk yang dilakukan lawan politik. Begitu juga sebalinya, ketika ingin membentuk image positif dari publik cukup dengan membanjiri media massa dengan hal-hal positif dari suatu partai atau kandidat. ${ }^{45}$

Pilar demokrasi di Indonesia saat ini yang masih bisa diandalkan hanya pers. Di tengah situasi negara yang kuat budaya korupsinya seperti Indonesia saat ini, pers hadir menjadi pilar yang masih bisa diharapkan. Pers menjadi bagian yang sering membelokkan hegemoni kekuasaan. Seperti membongkar kasus korupsi yang berusaha disembunyikan oleh eksekutif, legislatif dan yudikatif. Termasuk dalam mengawasi proses demokrasi dalam pemilu.

Pers memiliki peran yang sangat strategis, sehingga diharapkan bisa mendorong sesuatu hal yang dianggap melanggar untuk segera diselesaikan.

44 Jakob Oetomo, Pers Indonesia: Berkomunikasi dalam Masyarakat Tidak Tulus, (Jakarta: Kompas, 2003), hlm.76.

45 Firmansyah, Mengelola Partai Politik: Komunikasi dan Positioning Ideolgi Politik di Era Demokrasi, (Jakarta: Yayasan Obor Indonesia, 2008), hlm.28-29
Pers harus selalu menjaga keberimbangannya dalam melakukan pemberitaan. Ketimbang saat pemerintahan orde lama dan orde baru, Di era reformasi saat Ini kebebasan pers sudah lebih maju. Perlindungan terhadap perkerja pers masih sangat kurang, pers dinilai masih terancam posisinya oleh tiga kekuatan besar yang sangat dominan. Pertama, Negara. Meski pemerintah tidak melakukan kekerasan langsung terhadap insan pers, tapi terkesan adanya pembiaran terhadap kekerasan yang diterima pers. Kedua, para pemilik modal. Pemilik modal mendistorsi informasi-informasi yang tayang di media massa. Padahal, masyarakat memiliki hak mendapatkan informasi dengan bebas. Ketiga, kelompok masyarakat yang melakukan tindakan anarkis seperti terorisme, pembunuhan, penembakan, hingga surat ancaman.

Tiga pilar demokrasi di Indonesia saat ini baik legislatif, yudikatif dan eksekutif, dinilai samasama buruknya. Sehingga masyarakat tidak tahu lagi lembaga mana yang harus dijadikan acuan. Tiga pilar demokrasi tersebut sudah tidak bisa lagi diandalkan dalam membangun demokrasi di Indonesia. Di Lembaga legislatif, banyak anggota yang ditangkap dan diproses hukum karena terjerat kasu korupsi. Di lembaga yudikatif, banyak hakim, jaksa, polisi dan pengacara yang ditangkap karena kasus hukum itu sendiri. Hal yang sama juga terjadi di tubuh eksekutif. Sebanyak 167 orang secara resmi dinyatakan terlibat korupsi. Baik itu bupati, walikota, gubernur, mantan gubernur, dirjen, menteri dan mantan menteri. Kondisi pemberantasan korupsi di Indonesia masih jauh dari berhasil. Terus menerus kita mencatat 
perbuatan korup di ligeslatif, eksekutif dan yudikatif. Itulah sebabnya persepsi internasional tentang indeks korupsi di Indonesia masih sangat buruk. ${ }^{46}$

Tiga pilar demokrasi yang dinilai rusak tersebut sama sekali tidak sadar. Meski diketahui publik secara luas, permainan busuk antar lembaga eksekutif, legislatif dan yudikatif tidak berhenti. Indeks persepsi demokrasi Indonesia secara internasional disebut meningkat, tetapi kemajuannya hanya sebatas prosedural. Lembaga -lembaga eksekutif, legislatif dan yudikatif rawan dengan kasus - kasus korupsi. Di lembaga eksekutif kasus yang sering terjadi adalah mark up. Sedangkan kasus korupsi di lembaga legislatif dan yudikatif kasus yang paling dominan adalah suap yang dilakukan pihak luar demi melancarkan proyek dan memberikan putusan yang menguntungkan terdakwa atau tersangka. Lembaga legislatif juga mendapat predikat buruk dalam soal korupsi. ${ }^{47}$ Kepentingan politik transaksional yang dewasa ini mengakibatkan DPR lembaga terkorup di Indonesia. ${ }^{48}$

Saat sekarang ini motif dan bentuk kejahatan semakin beragam, sistemik, masif dan terorganisisr, yang paling parah lagi telah masuk di segala

${ }^{46}$ Tri Agung Kristanto dan Irwan Suhada ed, Jangan Bunuh KPK: Perlawanan Terhadap Usaha Pemberantasan Korupsi, (Jakarta: Kompas Media Nusantara, 2009), hlm.131.

47 Deni JA, Catatan Politik, (Yogyakarta: LKIS Yogyakarta, 2006) hlm.11.

${ }^{48}$ Wijayanto dan Ridwan Zachrie ed, Korupsi Mengkorupsi Indonesia: Sebab, Akibat, dan Prospek Pemberantasan, (Jakarta: Gramedia Pustaka Utama, 2010), hlm.471. lini baik di eksekutif, legislatif dan yudikatif. Termasuk di dalam lembaga penegak hukum yang seharusnya menjadi pilar terdepan dalam penegakkan hukum itu sendiri. Bahaya korupsi menyebabkan kerugian keuangan negara, perekonomian negara, stabilitas nasional, menghambat momentum pembangunan dan menurunkan kepercayaan masyarakat khususnya dunia internasional terhadap proses penegakkan hukum.

\section{Kesimpulan}

Negara demokratis didasari oleh sistem perwakilan demokratis yang menjamin kedaulatan rakyat. Keterwakilan (representasi) dibedakan menjadi dua hal perwakilan politik (political representation) dan perwakilan fungsional (functional representation). Beberapa kalangan merasa bahwa partai politik dan perwakilan yang berdasarkan kesatuankesatuan politik semata-mata mengabaikan berbagai kepentingan dan kekuatan lain yang ada di dalam masyarakat terutama di bidang ekonomi. ${ }^{49}$ Pebaikan akuntabilitas parlemen harus dimulai dari perbaikan akuntabilitas partai-partai politik. Sama seperti reformasi kelembagaan lainya, keberhasilan reformasi ini amat tergantung pada komitmen politik pimpinan parpol. ${ }^{50}$

Kalau kita meihat perjalanan dikelampauan sejarah kita, tampak dengan jelas fakta persoalan utama

\footnotetext{
49 Miriam Budiardjo, Dasar Dasar..., hlm.317

${ }^{50}$ Maria Hartiningsih ed, Korupsi Yang Memiskinkan, (Jakarta: Kompas Media Nusantara, 2001), hlm.288
} 
yang akan tetap dihadapi iyalah format sistem politik yang akan dikembangkan secara berkesinambungan. Artinya, sampai berapa mungkin pemimpin pemimpin bangsa - bangsa mampu menjalankan suatu sistem demokrasi yang membuka peluang bagi semua

\section{Daftar Kepustakaan}

Al-Maududi, Abu A'la. 1962. Islamic law and Constitution, translate and edited by Kurshid Ahmed. Lahore.

1995. Hukum dan Konstitusi; Sistem Politik Islam. Bandung: Mizan.

1988. Khilafah dan Kerajaan. Bandung: Mizan.

Al-Qardhawi, Yusuf. 2004. Larangan Berjilbab: Studi Khasus di Prancis. Jakarta: Gema Insani.

Amiruddin, Hasbi. 2000. Teori Kedaulatan Tuhan: Konsep Negara Islam Menurut Fazlur Rahman. Yogyakarta : UII Press.

Ali, Mukti. 1996. Alam Pikiran Islam Modern di India dan Pakistan. Bandung: Mizan.

Asshiddiqie, Jimly. 1994. Gagasan Kedaulatan Rakyat dalam Korstitusi dan Pelaksanaannya di Indonesia. Jakarta: Ichtiar Baru Van Hoeve. warga baik dalam pengertian warga yang menetap di daerah - daerah maupun dalam pengertian individu individu untuk memperoleh kesempatan mengambil peranan berdasarkan konstitusi yang berlaku

Asshidiqie, Jimly. 1995. Islam dan Kedaulatan Rakyat. Jakarta: Gema Insani Press.

Azwar, Saifuddin. 2013. Metode Penelitian. Yogyakarta: Pustaka Pelajar.

Arikunto, Suharsimi. 1990. Manajemen Penelitian. Jakarta: Rineka Cipta 1992. Prosedur Penelitian Suatu Pendekatan Praktek. Jakarta: Rineka Cipta.

Azari, Aidul Fitriciada. 2010. Tafsir Konstitusi: Pergulatan Mewujudkan Demokrasi di Indonesia. Solo: Jagad Abjad. 2005. Menumukan Demokrasi. Surakarta: Universitas Muhammadiyah Surakarta.

Alim, Muhammad. 2001. Demokrasi dan Hak Asasi Manusia dalam Konstitusi Madinah dan UUD 1945. Yogyakarta: UII Pres.

Alam, Wawan Tunggul. 2003. Demi Bangsaku Pertentangan Bung Karno vs Bung Hatta. Jakarta: Gramedia Pustaka Utama. 
Asshiddiqie, Jimly. 2007. Pokok-Pokok Hukum Tata Negara Indonesia Pasca Reformasi. Jakarta:BIP.

Atmaja, I Dewa Gede. 2011. Konsepsi Demokrasi dalam Bingkai Konstitusi, Malang: Setara Press.

Budisetyowati, Dwi Andayani. 2013. Kewenangan Mahkamah Konstitusi Republik Indonesia sebagai Dasar Pelindung Hak - Hak Warga Negara. Jakarta: Pustaka Masyarakat Setara.

Bodin, Jean. 1995. Six Books Of Commonwealth Blackwell's political texts. Michingan University : B. Blackwell.

Badan Pengembangan dan Pembinaan Bahasa. 2011. Kamus Bahasa Indonesia untuk Pelajar. Jakarta: Kementrian Pendidikan dan Kebudayaan.

Boyle, Kevin. 2000. Demokrasi: 80

Tanya Jawab. Yogyakarta: Kanisius.

Budiardjo, Miriam. 2010. Dasar-Dasar Ilmu Politik. Jakarta: Gramedia Pustaka Utama.

Deni JA. 2006. Catatan Politik. Yogyakarta:

LKIS Yogyakarta.

Dantes, Nyoman. 2012. Metodologi Penelitian. Yogyakarta: Andi.

Danim, Sudarwan. 2002. Menjadi Peneliti Kualitatif. Bandung: Pustaka Setia.
Eamage, E Douglas. 2002. Percaturan Politik di Indonesia: Demokrasi, Islam dan Ideologi Toleransi. Jogjakarta: Mata Bangsa.

Effendi, Bahtiar. 2001. Teologi Baru Agama Islam: Pertautan Agama, Negara dan Demokrasi. $\quad$ Yogyakarta: Galang Printika.

Fukuyama, Francis. 1992. The End of History and the Last Man. New York: Avon Books.

Firmansyah. 2008. Mengelola Partai Politik: Komunikasi dan Positioning Ideolgi Politik di Era Demokrasi. Jakarta: Yayasan Obor Indonesia.

Gray, Jerry. 2007. Demokrasi Barbar Ala Amerika. Jakarta: Sinergi Publishing.

Huda, Ni'matul. 2005. Negara Hukum, Demokrasi dan Judicial Review. Yogyakarta: UII Press.

Hadi, Sutrino. 1993. Metode Penelitian. Yogyakarta: Andi Offset.

Hasan, Fuad. 2006. Pengantar Filsafat Barat. Jakarta: Pustaka Jaya.

Huwaydi, Fahmi. 1993. Demokrasi Oposisi dan Masyarakat Madani. Bandung: Mizan.

Husaini, Adian. 2005. Wajah Peradaban Barat. Jakarta: Gema Insani. 
Hidayat, Komaruddin. 1994. Tiga Model Hubungan Agama dan Demokrasi.

Jakarta:Paramadina.

Haris, Syamsul. 2006. Proses Pencalona Legislatif Lokal: Pola, Kecenderungan Dan Profil Caleg. Jakarta: Gramedia Pustaka Utama.

Hartiningsih, Maria ed. 2011. Korupsi Yang Memiskinkan. Jakarta: Kompas Media Nusantara.

Ibrahim Khadar, Lathifah. 2005. Barat Memfitnah Islam. Jakarta: Gema Insani.

Ihza Mahendra, Yusril, 1999. Modernisme dan Fundamentalisme dalam Politik Islam. Jakarta: Paramadina.

Junadi, Yudi. 2011. Relasi Agama dan Negara: Redefinisi Diskursus Konstitusionalisme di Indonesia. Jakarta: IRM Press.

Esposito, John L dkk. 1996. Islam and

Democracy. New York: Oxford University Press.

Kaelan, 2012. Metode Penelitian Kualitatif Interdisipliner. Yogyakarta: Paradigma.

Kementrian Agama RI. 2007. AlQur'an Tajwid dan Terjemah. Bandung: Sygma Examedia Arkanleema.

Kuntowijoyo. 1997. Identitas Politik Umat Islam. Bandung: Mizan.
Karim, Abdul. 2004. Menggali Muatan Pancasila dalam Perspektif Islam. Yogyakarta: Surya Raya.

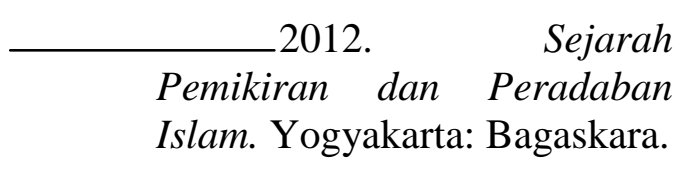

Kamaruzzaman. 2001. Relasi Islam dan Negara. Magelang: Indonesiatera.

Lexy J, Moleong. 2007. Metodologi Penelitian Kualitatif. Bandung: Remaja Rosdakarya.

Lewis, Bernard. 2002. Islam Liberalisme Demokrasi: Membangun Sinergi Warisan Sejarah, Doktrin, dan Konteks Global. Jakarta: Paramadina.

Mufti, Muslim dkk. 2013. Teori-teori Demokrasi. Bandung: Pustaka Setia.

Muslim, Mufti. 2012. Teori-teori Politik. Bandung: Pustaka Setia.

Marzuki. 2002. Metodologi Riset. Yogyakarta: FE UII.

Mardalis. 2002. Metode Penelitian: Suatu Pendekatan Proposal. Jakarta: Bumi Aksara.

M. Zuhri. 2004. Potret Keteladanan Kiprah Politik Muhammad Rasulullah. Jakarta: LESFI.

Nasution. 1988. Metoda Penelitian Naturalistik Kualitatif. Bandung: Tarsito. 
1996. Metodologi Research: Penelitian Ilmiah. Jakarta: Bumi Aksara.

Nasir. 1985. Metode Penelitian. Jakarta: Ghalia Utama.

Nasucha, Yakub, dkk. 2009. Bahasa Indonesia Untuk Penulisan Karya Tulis Ilmiah. Yogyakarta: Media Perkasa.

Oetomo, Jakob. 2003. Pers Indonesia: Berkomunikasi dalam Masyarakat Tidak Tulus. Jakarta: Kompas.

Purnama, Eddy. 2007. Negara Kedaulatan Rakyat: Analisis Terhadap Sistem

Pemerintahan Indonesia dan Pebandingannya dengan Negara Lain. Bandung: Nusamedia.

Pascasarjana. 2013. Pedoman Penulisan Tesis. Surakarta: Universitas Muhammadiyah Surakarta.

Perry, Marvin. 1997. Western Civilization: A Brief History. Boston: Houghton Mifflin Company.

Qadir Hamid, Tijani. 2001. Pemikiran Politik dalam Al-Qur'an. Jakarta: Gema Insani.

Rais, Dhiauddin. 2011. Teori Politik Islam. Jakarta: Gema Insani Press.

Sihbudi, Muhammad Rizza. 2004. Islam, Radikalisme dan Demokrasi. Jakarta: LIPI.
Sugiyono. 2005. Memahami Penelitian Kualitatif. Bandung: Alfabeta.

Suhelmi, Ahmad. 2001. Pemikir Politik Barat. Jakarta: PT Gramedia Pustaka Utama.

Sjadzali, Munawir. 1993. Islam dan Tata Negara: Ajaran, Sejarah dan Pemikiran. Jakarta: Universitas Indonesia Press.

Sulemen, Zulfikri. 2010. Demokrasi Untuk Indonesia: Pemikiran Politik Bung Hatta. Jakarta: Kompas Media Nusantara.

Shamsur, Rahman. 1977. Spain e Musalmander Itihash. Khulna: Piramaund Press.

Semma, Masyur. 2008. Negara dan Korupsi: Pemikiran Mochtar Lubis Atas Negara, Manusia Indonesia dan Perilaku Politik. Jakarta:Yayasan Obor Indonesia.

Sudibyo,Agus. 2004. Ekonomi Politik Media Penyiaran, Yogyakarta: LKIS.

Tanjung, Akbar. 2007. The Golkar Way: Survival Partai Golkar di Tengah Turbulensi Politik Era Transisi. Jakarta:Gramedia Pustaka Utama.

Vaezi, Ahmed. 2001. Agama Politik: Nalar Politik Islam. Jakarta: Citra.

Winarno dkk. 1982. Penelitian Ilmiah, Dasar, Metode, teknik. Bandung: Tarsito 
Wijayanto dan Ridwan Zachrie ed. 2010. Korupsi Mengkorupsi Indonesia: Sebab, Akibat, dan Prospek Pemberantasan. Jakarta: Gramedia Pustaka Utama.

Zada, Khamami. Dkk. 2007. Fiqh Siyasah: Doktrin dan
Pemikiran Politik Islam. Jakarta: Erlangga.

Zuelva, Hamdan. 2012. Pelembagaan Nilai-Nilai Pancasila dalam Perspektif Kehidupan Beragama, Sosial dan Budaya Melalui Putusan Mahkamag Konstitusi". Yogyakarta: PSP UMS. 